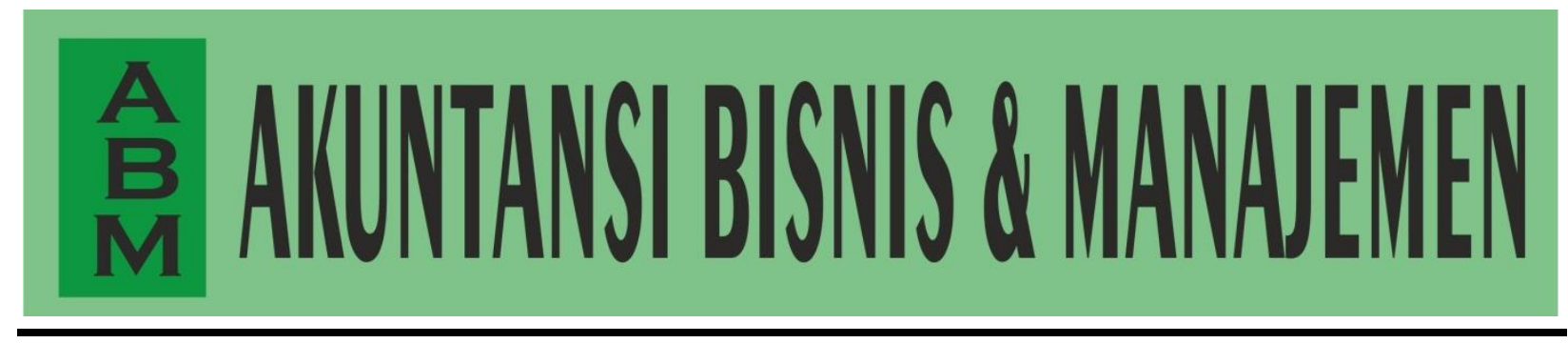

\title{
LITERASI PAJAK, KUALITAS PELAYANAN, SANKSI PERPAJAKAN DAN KEPATUHAN WAJIB PAJAK UMKM
}

\author{
Ni Nyoman Yuliati') dan Agus Khazin Fauzi ${ }^{2)}$ \\ 1,2)Sekolah Tinggi Ilmu Ekonomi AMM, Mataram, Lombok NTB \\ Jalan Pendidikan Nomor 1 Mataram, NTB \\ E-Mail:ozie3889@gmail.com
}

DOI: https://doi.org/10.35606/jabm.v27i2.668

\author{
Akuntansi Bisnis dan \\ Manajemen (ABM), \\ Vol. 27 \\ No. 02 \\ Halaman 26-44 \\ Bulan Oktober, Tahun 2020
}

ISSN 0854-4190

E-ISSN 2685-3965

\begin{abstract}
This study aims to analyze the influence of tax literacy, service quality, and tax sanctions on the compliance level of SME taxpayers. The type of research used in this research is associative. The data used by quisioner primary from of technical data. The population of this research is the SME taxpayers in the trade sector listed. Samples were taken using non-propability sampling, namely incidental sampling. The number of questionnaires that can be analyzed is 40 questionnaires. Data analysis tehniques used in this research is descriptive analysis and multiple regressions. The results of this study indicate that tax literacy and service quality do not have a significant effect on SME taxpayer compliance, while tax sanctions have a significant effect on SME taxpayer compliance.
\end{abstract}

Keywords: Tax Literacy; Service Quality; Tax Sanctions; SME; Taxpayer Compliance

\section{Abstrak}

Penelitian ini bertujuan untuk menganalisis pengaruh literasi pajak, kualitas pelayanan, dan sanksi perpajakan terhadap kepatuhan wajib pajak UMKM. Jenis penelitian yang digunakan dalam penelitian ini adalah asosiatif. Data yang digunakan berupa data primer dengan teknik kuesioner. Populasi penelitian ini adalah wajib pajak UMKM di sektor perdagangan yang terdaftar di KPP Pratama Praya. Sampel diambil dengan menggunakan non probability sampling yaitu sampling insidental. Jumlah kuesioner yang bisa dianalisis sebanyak 40 kuesioner. Teknik Analisis data dalam penelitian ini menggunakan analisis deskriptif dan regresi berganda. Hasil penelitian ini menunjukan bahwa literasi pajak dan kualitas pelayanan tidak berpengaruh signifikan terhadap kepatuhan wajib pajak UMKM, sedangkan sanksi perpajakan berpengaruh signifikan terhadap kepatuhan wajib pajak UMKM.

Keywords: Literasi Pajak; Kualitas Pelayanan; Sanksi Perpajakan; Kepatuhan Wajib Pajak; UMKM. 


\section{PENDAHULUAN}

Salah satu sumber pendapatan negara yang berasal dari kontribusi masyarakat yang digunakan untuk membiayai pengeluaran pemerintah dan mendanai pembangunan adalah pajak. Menurut Undang-Undang Nomor 28 Tahun 2007 tentang Ketentuan Umum dan Tata Cara Perpajakan disebutkan bahwa pajak merupakan kontribusi wajib kepada negara yang terutang oleh pribadi atau badan yang bersifat memaksa berdasarkan Undang-Undang, dengan tidak mendapatkan imbalan secara langsung dan digunakan untuk keperluan negara bagi sebesar-besarnya kemakmuran rakyat. Jika melihat definisi tersebut maka salah satu fungsi pajak adalah fungsi penerimaan (budgetair). Hal ini bermakna bahwa kontribusi dan peranan pajak sangatlah penting dan potensial dalam perekonomian Indonesia dikarenakan pajak merupakan sumber utama bagi negara untuk mendanai Anggaran Pendapatan dan Belanja Negara (Masruroh \& Zulaikha, 2013) sebagaimana tersaji pada tabel di bawah ini.

Tabel 1.

Proporsi Penerimaan Negara Tahun 2016-2019 (dalam milyaran rupiah)

\begin{tabular}{ccccc}
\hline Tahun & $\begin{array}{c}\text { Pendapatan } \\
\text { Pajak }\end{array}$ & PNBP & Total & $\begin{array}{c}\text { Prosentase } \\
\text { Penerimaan } \\
\text { Pajak }\end{array}$ \\
\hline 2016 & $1.284 .970,10$ & $261.976,30$ & $1.546 .946,60$ & $83 \%$ \\
2017 & $1.343 .529,80$ & $311.216,30$ & $1.654 .746,10$ & $81 \%$ \\
2018 & $1.518 .789,80$ & $409.320,20$ & $1.928 .110,00$ & $79 \%$ \\
2019 & $1.643 .083,90$ & $386.333,90$ & $2.029 .417,80$ & $81 \%$ \\
\hline
\end{tabular}

Sumber : bps.go.id

Berdasarkan Tabel 1 diketahui bahwa, penerimaan negara yang berasal dari sektor perpajakan selalu menduduki persentase di atas $70 \%$. Melalui data tersebut, dapat dibuktikan bahwa pajak merupakan sumber penerimaan terbesar bagi negara. Pemerintah dalam hal ini Direktorat Jenderal Pajak terus berupaya untuk memaksimalkan penerimaan pajak mengingat akan besarnya peranan pajak untuk menggerakkan roda pemerintah dan pembangunan sehingga tentu saja hal itu harus didukung oleh peran serta wajib pajak dalam melaksanakan kewajiban perpajakannya. Di sisi lain, dalam hal praktiknya, upaya untuk meningkatkan kontribusi wajib pajak dalam pembayaran pajak masih belum mendapatkan hasil yang sesuai dengan yang diharapkan. Lihat saja misalnya berkaitan dengan pemberlakuan pajak Usaha Mikro Kecil Menengah (UMKM) dimana berdasarkan data dari (Depkop, 2018) jumlah UMKM sebanyak 64.194.057 ternyata yang patuh membayar pajak pada tahun 2019 tercatat sebanyak 2,31 juta WP yang terdiri dari 2,05 juta WP OP dan 257.000 WP Badan (Mucglobal, 2020). Jika dilihat dari data tersebut, jumlah wajib pajak UMKM tidak diimbangi dengan pertumbuhan jumlah UMKM yang ada sehingga dapat dikatakan bahwa kesadaran pemilik UMKM dalam melaksanakan kewajiban perpajakannya terbilang rendah, walaupun dalam hal ini pemerintah telah memangkas pajak penghasilan yang bersifat final untuk usaha mikro kecil dan menengah dari tarif semula 1\% menjadi 0,5\% melalui pemberlakuan PP Nomor 23 Tahun 2018. 
Penurunan tarif pajak menjadi $0,5 \%$ bagi pelaku UMKM dirasakan masih terlalu memberatkan dikarenakan pemberlakuan tarif baru tersebut masih tidak memandang wajib pajak untung ataupun rugi di samping pelaku UMKM beranggapan bahwa pengenaan pajak UMKM sebesar 0,5\% dari peredaran bruto masih saja dianggap tidak menguntungkan perusahaan karena para pengusaha UMKM merasa masih terbebani dengan adanya biaya-biaya tambahan dalam proses produksi (Pertiwi, 2020). Tidaklah mengherankan, ketika tax ratio (perbandingan atau persentase penerimaan pajak terhadap produk domestik bruto (PDB) Indonesia pada tahun 2019 hanya 10,7 persen mengalami penurunan dibandingkan pada tahun 2018 yakni 11,5 persen. Kondisi tersebut terjadi dikarenakan wajib pajak masih seringkali melakukan upaya penghindaran pajak yang berdampak terhadap rendahnya kepatuhan wajib pajak itu sendiri. Kepatuhan dalam hal ini berarti tunduk atau patuh pada ajaran atau aturan. Dengan demikian, kepatuhan wajib pajak berarti kondisi dimana wajib pajak memenuhi segala kewajiban perpajakan dan melaksanakan hak perpajakannya (Wardani \& Wati, 2018).

Upaya meningkatkan kepatuhan wajib pajak tidaklah mudah untuk dilakukan walaupun sistem perpajakan di Indonesia telah menganut self assessment system yaitu sebuah sistem yang mengharuskan wajib pajak untuk mendaftar, menghitung, membayar serta melaporkan sendiri jumlah pajak terutang yang menjadi kewajiban mereka (Supadmi, 2009). Salah satu penyebab rendahnya kepatuhan wajib pajak adalah rendahnya literasi masyarakat di bidang perpajakan. Menurut (Saputro, 2018) literasi berkaitan dengan kemampuan seseorang dalam membaca informasi, memahami informasi dan menindaklanjuti informasi melalui suatu keputusan yang berguna dalam hidup. Artinya bahwa literasi pajak berhubungan dengan segala pengetahuan dan pemahaman perpajakan yang dimiliki oleh wajib pajak dan bagaimana wajib pajak tersebut menindaklanjuti pengetahuan yang dimilikinya. Dengan demikian, literasi merupakan salah satu alternatif untuk mewujudkan masyarakat sadar pajak. Hal ini diperkuat dengan apa yang dikemukakan oleh (Ibda, 2019) bahwa konsep dan praktik literasi perpajakan intinya sama seperti program edukasi sadar pajak yang telah diinisasi Dirjen Pajak Kementerian Keuangan Republik Indonesia. Melalui edukasi tersebut tentunya pengetahuan dan pemahaman seorang wajib pajak terhadap peraturan perpajakan akan mengalami peningkatan dan wajib pajak menyadari bahwa peran pajak sangat penting. Hal ini nantinya akan berdampak terhadap peningkatan kepatuhan wajib pajak (Astina \& Setiawan, 2018). Sebagaimana hasil penelitian yang telah dilakukan oleh (Fahluzy \& Agustina, 2014; Febriani \& Kusmuriyanto, 2015; Ilhamsyah et al., 2016; Tambun, 2016; Wiyarni, Hartini, Djuharni, 2018) menemukan bahwa variabel pengetahuan dan pemahaman pajak berpengaruh signifikan terhadap kepatuhan wajib pajak. Namun berbeda dengan penelitian (Hardiningsih \& Yulianawati, 2011) justru menemukan bahwa pengetahuan seorang wajib pajak tentang aturan perpajakan tidak mempengaruhi kepatuhan wajib pajak. Begitu juga penelitian dari (Roseline \& Rusydi, 2012) bahwa pengetahuan dan pemahaman tentang peraturan perpajakan tidak mempengaruhi kepatuhan wajib pajak dalam mengukuhkan diri sebagai pengusaha kena pajak.

Faktor lain yang mempengaruhi kepatuhan wajib pajak adalah kualitas pelayanan. Menurut (Astina \& Setiawan, 2018) yang mengutip dari (Cronin, 1992) 
mengungkapkan bahwa kualitas pelayanan dapat dinilai dari perbandingan antara harapan yang diinginkan oleh pelanggan dengan penilaian mereka terhadap kinerja aktual dari suatu penyediaan layanan. Dengan demikian, untuk meningkatkan kepatuhan wajib pajak dalam memenuhi kewajiban perpajakannya maka kualitas pelayanan harus diutamakan oleh aparat pajak, sehingga semakin baik kualitas pelayanan yang diberikan oleh fiskus maka akan memberikan kepuasan kepada wajib pajak yang semakin tinggi dan meningkatkan kepatuhan wajib pajaknya (Astina \& Setiawan, 2018; Supadmi, 2009). Sebagaimana penelitian yang dilakukan oleh (As'ari \& Erawati, 2018; Pranata \& Setiawan, 2015; Rustiyaningsih, 2017) membuktikan bahwa kualitas pelayanan yang diberikan petugas pajak mempengaruhi kepatuhan wajib pajak. Sejalan dengan itu Berbeda dengan hasil penelitian (Fauziah \& Kusmuriyanto, 2016; Masruroh \& Zulaikha, 2013) menunjukkan justru kualitas pelayanan tidak berpengaruh terhadap kepatuhan wajib pajak. Begitu juga penelitian (Brata et al., 2017) menemukan bahwa pelayanan fiskus memberikan pengaruh tidak signifikan dan mempunyai hubungan yang negatif terhadap kepatuhan wajib pajak.

Tidak hanya itu saja, sanksi perpajakan yang telah diatur dalam ketentuan umum dan tata cara perpajakan juga diduga mempengaruhi kepatuhan wajib pajak. Sanksi menurut (Mardiasmo, 2018) adalah tindakan berupa hukuman yang diberikan kepada orang yang melanggar peraturan perundang-undangan di bidang perpajakan, dimana sanksi tersebut berupa sanksi administrasi, pidana ataupun keduanya. Pemberian sanksi ini dimaksudkan untuk mendidik dan menghukum sehingga memberikan pelajaran bagi pelanggar pajak untuk mencegah ketidakpatuhan wajib pajak. Penelitian (Brata et al., 2017; Pranata \& Setiawan, 2015; Rahayu, 2017) menemukan bahwa sanksi perpajakan berpengaruh signifikan terhadap kepatuhan wajib pajak. Namun berbeda dengan penelitian (Fauziah \& Kusmuriyanto, 2016; Rahmawati \& Yulianto, 2018) justru menemukan sebaliknya bahwa sanksi perpajakan tidak berpengaruh signifikan terhadap kepatuhan wajib pajak.

Berdasarkan uraian permasalahan di atas dan ketidakkonsistenan hasil penelitian terdahulu maka peneliti tertarik untuk meneliti mengenai pengaruh literasi pajak, kualitas pelayanan dan sanksi perpajakan terhadap kepatuhan wajib pajak UMKM di Praya. Hasil dari penelitian ini diharapkan mampu memberikan manfaat kepada pemangku kebijakan yang dalam hal ini Direktorat Jenderal Pajak di unit-unit Kantor Pelayanan Pajak untuk mengevaluasi kebijakan yang diambil dalam bidang perpajakan sehingga dapat meningkatkan antusiasme wajib pajak untuk memenuhi kewajiban perpajakannya yang berdampak terhadap tingkat kepatuhan wajib pajak yang meningkat.

\section{KAJIAN PUSTAKA Pajak UMKM}

Menurut Undang-Undang Nomor 16 tahun 2009 dijelaskan tentang pajak adalah kontribusi wajib kepada negara yang terutang oleh orang pribadi atau badan yang bersifat memaksa berdasarkan Undang-Undang, dengan tidak mendapatkan imbalan secara langsung dan digunakan untuk keperluan negara bagi sebesar-besarnya kemakmuran rakyat. Pemerintah dalam hal ini Direktorat Jenderal Pajak (DJP) telah melakukan berbagai upaya dalam rangka meningkatkan kepatuhan wajib dan mengoptimalkan penerimaan pajak yang salah satu kegiatannya adalah ekstensifikasi. 
Kegiatan ekstensifikasi berkaitan dengan penambahan jumlah wajib pajak melalui Sensus Pajak Nasional (SPN) yaitu perluasan jumlah wajib pajak untuk mencapai dan mengamankan target penerimaan pajak dimana dalam hal ini DJP berusaha untuk menjaring wajib pajak usaha, mikro kecil dan menengah (UMKM) (Yusro \& Kiswanto, 2014). Perlu diketahui bahwa klasifikasi UMKM berdasarkan Undang-Undang Nomor 20 Tahun 2008 tentang Usaha Mikro, Kecil dan Menengah dapat dibedakan dari jumlah aset dan total omzet penjualannya.

Berdasarkan data dari (Depkop, 2018) jumlah UMKM pada tahun 2018 mencapai 64.194.057 dimana jumlah ini tidak sebanding dengan jumlah wajib pajak terdaftar yang hanya 2,3 juta wajib pajak pada tahun 2019. Jika melihat dari tersebut tentunya tingkat kesadaran masyarakat untuk membayar pajak khususnya UMKM masih terbilang rendah/minim (Mucglobal, 2020). Menyikapi hal tersebut, pemerintah telah mengeluarkan peraturan yang mengatur tentang pajak UMKM yaitu Peraturan Pemerintah Nomor 23 Tahun 2018 mengenai pajak penghasilan atas penghasilan dari usaha yang diterima atau diperoleh wajib pajak yang memiliki peredaran bruto tertentu yang berlaku sejak 1 Juli 2018. Peraturan yang dikeluarkan tersebut merupakan revisi dari peraturan sebelumnya yang sudah dikeluarkan yaitu Peraturan Pemerintah Nomor 46 Tahun 2013. Dalam Peraturan Pemerintah Nomor 23 Tahun 2018, terjadi penurunan tarif PPh Final yang semula 1 \% menjadi 0,5\%. Meskipun pendapatan pemerintah akan berkurang dikarenakan penurunan tarif pajak UMKM akan tetapi pemerintah optimis dengan adanya penurunan tarif tersebut, kesadaran wajib pajak UMKM akan meningkat baik dalam hal membayarkan pajaknya maupun mendaftarkan diri menjadi wajib pajak sehingga pendapatan negara dari sektor perpajakan UMKM akan meningkat pula. Alasan lain pemerintah menurunkan tarif adalah untuk membantu pengembangan usaha para UMKM dan juga untuk menjaga arus kas supaya dapat digunakan sebagai tambahan modal sehingga tidak ada alasan lagi untuk para pelaku UMKM tidak menjalankan kewajiban perpajakannya (Wulandari, 2020)

\section{Kepatuhan Wajib Pajak}

Dalam kamus umum Bahasa Indonesia (Kementerian Pendidikan dan Kebudayaan, 2016), kepatuhan diartikan dengan patuh atau taat. Patuh atau taat dalam hal ini berarti mematuhi atau tunduk pada peraturan perundang-undangan yang berlaku. Dengan demikian, kepatuhan wajib pajak ditandai dengan keadaan saat wajib pajak memenuhi semua kewajiban perpajakan dan melaksanakan hak perpajakannya yang bisa dilihat dari wajib pajaknya mulai mendaftarkan diri, mencatat semua penghasilan kena pajak, membayar pajak terutang hingga melaporkan pajak sesuai dengan ketentuan peraturan perundang-undangan (menganut self assessment system) (Febriani \& Kusmuriyanto, 2015). Seseorang dalam menentukan perilaku patuh atau tidak patuh dalam memenuhi kewajiban perpajakannya dipengaruhi rasionalitas dalam mempertimbangkan manfaat dari pajak dan juga pengaruh orang lain yang mempengaruhi keputusan dalam patuh pajak. Hal ini sejalan dengan apa yang dikemukakan oleh (Mangoting \& Sadjiarto, 2013) bahwa pada dasarnya kepatuhan wajib pajak dipengaruhi oleh dua faktor yaitu faktor internal yang merupakan faktor yang berasal dari diri wajib pajak sendiri dan berhubungan dengan karakteristik 
individu yang menjadi pemicu dalam menjalankan kewajiban perpajakannya dan faktor eksternal yang berasal dari luar diri wajib pajak sebagaimana diungkapan dalam beberapa penelitian bahwa seorang wajib pajak yang patuh biasanya ditandai dengan wajib pajak yang secara sukarela mendaftarkan diri ke Kantor Pelayanan Pajak, wajib pajak yang menghitung pajak dengan benar dan patuh dalam menyetorkan dan melaporkan pajak (Febriani \& Kusmuriyanto, 2015) maupun wajib pajak yang mengisi dengan jujur, lengkap dan benar surat pemberitahuan (SPT) sesuai dengan ketentuan peraturan perundang-undangan (Rahayu, 2017).

\section{Literasi Pajak}

Literasi sebagaimana dijelaskan dalam kamus besar bahasa Indonesia adalah kemampuan menulis dan membaca, pengetahuan dan keterampilan dalam bidang atau aktivitas tertentu dan kemampuan mengolah informasi dan pengetahuan (Kementerian Pendidikan dan Kebudayaan, 2016). Jadi, literasi sadar pajak adalah sebuah upaya meningkatkan daya cerna masyarakat terhadap pajak sehingga melahirkan kesadaran untuk menjadi orang bijaksana yang taat pajak (Saputro, 2018). Konsep dan praktik literasi perpajakan intinya sama seperti program edukasi sadar pajak yang telah diinisasi Dirjen Pajak Kementerian Keuangan Republik Indonesia, sehingga melalui literasi pajak seorang wajib pajak akan memiliki pengetahuan dan pemahaman terhadap peraturan perpajakan dan melahirkan kesadaran dan taat pajak (Ibda, 2019). Adapun bentuk literasi pajak meliputi pengetahuan dan pemahaman tentang tarif pajak, sanksi pajak, kepemilikan NPWP, penghitungan pajak dengan benar, cara menyampaikan SPT, pembayaran pajak terutang, tempat pembayaran, denda dan batas waktu pembayaran atau pelaporan SPT (Ilhamsyah et al., 2016; Rahayu, 2017; Rustiyaningsih, 2017). Sering berubahnya peraturan perpajakan merupakan salah satu hal yang membuat wajib pajak tidak patuh, karena hal tersebut membuat sebagian wajib pajak menjadi bingung yang mengakibatkan ketidakpahaman dan ketidakmengertian mereka (Wiyarni et al.,2018).

\section{Kualitas Pelayanan}

Menurut (Supadmi, 2009), kualitas diartikan sebagai suatu kondisi yang dinamis dan berhubungan dengan jasa manusia, proses, produk dan lingkungan yang memenuhi dari harapan seseorang/pihak yang menginginkannya. (Pranata \& Setiawan, 2015) yang mengutip dari (Hidayat, 2010), mengemukakan bahwa pelayanan terjadi melalui interaksi manusia, kontak antara layanan pelanggan dengan karyawan dan selama pelayanan berlangsung sangat menentukan kualitas pelayanan yang disampaikan kepada pelanggan. Sejalan dengan hal itu, (Brata et al., 2017) menyampaikan bahwa pelayanan pajak dapat dikaitkan dengan normative beliefs yaitu kondisi dimana ketika akan melakukan sesuatu, individu akan memiliki keyakinan tentang normatif dari orang lain dan motivasi untuk memenuhi harapan tersebut. Dengan demikian, kualitas pelayanan yang baik ditandai dengan pelaksanaan sistem perpajakan yang efisien dan efektif maupun kemampuan pelayanan fiskus yang memuaskan yang membuat wajib pajak merasa nyaman dalam melaksanakan kewajiban perpajakannya (Febriani \& Kusmuriyanto, 2015). Ada lima dimensi yang digunakan untuk menilai kualitas pelayanan yang diberikan oleh kantor pajak sebagaimana dikemukakan oleh (Wulan \& Joharis, 2012) yaitu: 1) Kehandalan (reliability); berkaitan dengan kemampuan aparat pajak (kantor pajak) untuk 
memberikan pelayanan yang akurat sejak pertama kali tanpa membuat kesalahan apapun dan menyampaikan pelayanan sesuai dengan waktu yang telah disepakati, 2) Daya tanggap (responsiveness); berkenaan dengan kesiapan dan kemampuan aparat pajak (kantor pajak) untuk membantu pelanggan (WP) dan merespons permintaan mereka,serta menginformasikan kapan pelayanan akan diberikan dan kemudian memberikan pelayanan secara cepat, 3) Jaminan (assurance); berkaitan dengan perilaku aparat pajak (kantor pajak) yang mampu menumbuhkan kepercayaan dan menciptakan rasa aman bagi pelanggan (wajib pajak). Jaminan juga berarti bahwa aparat pajak (kantor pajak) selalu bersikap sopan dan menguasai pengetahuan dan keterampilan yang dibutuhkan untuk menangani setiap pertanyaan atau masalah W, 4). Empati (empati); berarti aparat (kantor pajak) memahami masalah pelanggan (wajib pajak) dan bertindak demi kepentingan wp, serta memberikan perhatian personal kepada wp dan memiliki jam operasi yang nyaman dan 4). Bukti fisik (tangibles); berkenaan dengan daya tarik fasilitas fisik, perlengkapan, dan material yang digunakan aparat pajak (kantor pajak) serta penampilan dari aparat pajak.

\section{Sanksi Perpajakan}

Dalam peraturan perundang-undangan perpajakan, setiap orang dengan sengaja tidak mendaftarkan diri untuk diberikan nomor pokok wajib pajak (NPWP), atau menyalahgunakan atau menggunakan tanpa hak NPWP yang menimbulkan kerugian pada pendapatan negara maka akan dikenakan yang namanya sanksi. (Mardiasmo, 2018) menjelaskan bahwa sanksi pajak merupakan jaminan ketentuan peraturan perundang-undangan perpajakan (norma perpajakan) akan dituruti/ditaati/dipatuhi dimana pengenaan sanksi ini sebagai pencegah agar wajib pajak tidak melanggar norma perpajakan. Ketegasan sanksi bagi pelanggar aturan perpajakan perlu ditegakkan dan dilaksanakan secara tegas untuk memberikan efek jera. Dalam Undang-Undang Nomor 28 Tahun 2007 tentang Ketentuan Umum dan Tata Cara Perpajakan, terdapat dua macam sanksi yaitu 1) sanksi administrasi yang terdiri dari sanksi berupa denda, sanksi berupa bunga dan sanksi berupa kenaikan, 2) sanksi pidana yang terdiri dari sanksi pidana kurungan dan sanksi penjara.

\section{Pengembangan Hipotesis}

\section{Pengaruh Literasi Pajak Terhadap Kepatuhan Wajib Pajak UMKM}

Literasi pajak pada dasarnya adalah daya cerna masyarakat terhadap pajak yang melahirkan kesadaran untuk menjadi orang bijaksana yang taat pajak (Saputro, 2018). Melalui literasi pajak ini maka wajib pajak akan memiliki pengetahuan dan pemahaman terhadap peraturan perpajakan. Artinya bahwa wajib pajak yang tahu, paham dan sadar tentang pajak tidak akan berfikir bahwa bahwa pajak merupakan suatu beban yang memberatkan tetapi justru menyadari bahwa peran pajak sangatlah penting bagi pembiayaan pembangunan negara (Astina \& Setiawan, 2018; Fahluzy \& Agustina, 2014). Oleh karena itu, adanya pengetahuan dan pemahaman wajib pajak mengenai peraturan perpajakan akan melahirkan kesadaran dan ketaatan wajib pajak untuk memenuhi kewajiban perpajakannya yang tentunya hal tersebut akan berdampak pula terhadap peningkatan kepatuhan wajib pajak. Sebagaimana hasil penelitian yang dilakukan oleh (Fahluzy \& Agustina, 2014; Febriani \& Kusmuriyanto, 2015; Ilhamsyah et al., 2016; Tambun, 2016) bahwa pengetahuan dan pemahaman 
seorang wajib pajak berpengaruh signifikan terhadap kepatuhan wajib pajak. Berdasarkan uraian tersebut dapat dirumuskan hipotesis sebagai berikut:

$\mathrm{H}_{1}$ : Literasi pajak berpengaruh signifikan terhadap kepatuhan wajib pajak UMKM

\section{Pengaruh Kualitas Pelayanan Terhadap Kepatuhan Wajib Pajak UMKM}

Pelayanan adalah usaha yang dilakukan oleh kantor pelayanan pajak dalam hal ini bagaimana kantor pajak melayani wajib pajak secara maksimal agar wajib pajak tidak mengalami kendala-kendala saat memenuhi kewajiban perpajakannya dan memberikan kepuasan kepada wajib pajak. Kepatuhan wajib pajak berhubungan erat dengan kualitas pelayanan sebagaimana dikemukakan oleh (Robbins \& Judge, 2008) yang dikutip dari (Fauziah \& Kusmuriyanto, 2016) dalam teori pembelajaran sosial dijelaskan bahwa seorang wajib pajak akan taat membayar pajak apabila wajib pajak mempunyai pengalaman langsung mengenai pelayanan yang diberikan oleh fiskus. Apabila kualitas pelayanan yang diberikan baik dan wajib pajak puas tentang pelayanan tersebut maka wajib pajak akan taat membayar pajak dan kepatuhan wajib pajak akan meningkat. Hal ini juga sejalan dengan yang dikemukakan oleh (Febriani \& Kusmuriyanto, 2015) bahwa apabila petugas pajak mampu memberikan pelayanan yang memuaskan maka wajib pajak tentunya akan merasa nyaman dalam memenuhi kewajiban perpajakannya dan kepatuhan wajib pajak akan meningkat. Beberapa riset juga telah membuktikan bahwa kualitas pelayanan mempengaruhi kepatuhan wajib pajak seperti penelitian (As'ari \& Erawati, 2018; Pranata \& Setiawan, 2015; Rustiyaningsih, 2017). Berdasarkan uraian tersebut dapat dirumuskan hipotesis sebagai berikut :

$\mathrm{H}_{2}$ : Kualitas pelayanan berpengaruh signifikan terhadap kepatuhan wajib pajak UMKM

\section{Pengaruh Sanksi Perpajakan Terhadap Kepatuhan Wajib Pajak UMKM}

Sanksi adalah suatu tindakan berupa hukuman yang diberikan kepada orang yang melanggar peraturan. Sanksi diperlukan agar peraturan atau Undang-undang tidak dilanggar, agar peraturan perpajakan dipatuhi, maka harus ada sanksi perpajakan bagi para pelanggarnya. Wajib pajak akan mematuhi pembayaran pajak apabila mereka menganggap bahwa sanksi pajak yang akan dikenakan apabila tidak membayar pajak akan sangat merugikannya sehingga semakin tegas sanksi ditegakkan maka wajib pajak akan semakin patuh (Brata et al., 2017; Fauziah \& Kusmuriyanto, 2016). Dalam teori pembelajaran sosial yang dikembangkan oleh (Robbins \& Judge, 2008) bahwa wajib pajak dapat belajar dan mengamati wajib pajak lain yang mendapat sanksi apabila melanggar norma perpajakan sehingga pengamatan dan pengalaman langsung tersebut menjadi dasar bagi wajib pajak untuk menilai pemberian sanksi dan memilih berperilaku patuh atau tidak. Beberapa riset terdahulu telah membuktikan bahwa sanksi perpajakan dapat mempengaruhi kepatuhan wajib pajak diantaranya penelitian (Brata et al., 2017; Pranata \& Setiawan, 2015; Rahayu, 2017). Berdasarkan uraian tersebut dapat dirumuskan hipotesis sebagai berikut:

$\mathrm{H}_{3}$ : Sanksi perpajakan berpengaruh signifikan terhadap Kepatuhan Wajib Pajak UMKM 


\section{METODE PENELITIAN}

Penelitian ini termasuk kategori penelitian asosiatif yaitu untuk mengetahui dan menganalisis hubungan antara literasi pajak, kualitas pelayanan dan sanksi perpajakan terhadap kepatuhan wajib pajak UMKM. Populasi dalam penelitian ini adalah UMKM yang terdaftar di KPP Pratama Praya yang bergerak di sektor perdagangan berjumlah 20.565. Jumlah sampel ditentukan dengan rumus slovin sehingga diperoleh ukuran sampel sebanyak 99,5 yang dibulatkan menjadi 100. Dalam pengambilan sampel, peneliti menggunakan teknik non probability sampling yaitu sampling insidental merupakan teknik penentuan sampel berdasarkan kebetulan, yaitu siapa saja wajib pajak UMKM di sektor perdagangan yang secara kebetulan bertemu dengan peneliti dan dipandang cocok dapat dijadikan sebagai sampel. Pengumpulan data dilakukan dengan metode survey menggunakan kuesioner yaitu teknik pengumpulan data yang dilakukan dengan cara memberikan seperangkat pertanyaan tertulis kepada responden untuk menjawabnya (Sugiyono, 2019). Untuk mengukur masing-masing indikator dari variabel diberikan nilai kategori secara individual dengan menggunakan skala likert 5 poin. Dari jumlah kuesioner yang disebarkan sebanyak 100, diperoleh jumlah sampel yang dapat diolah dan dianalisis berjumlah 40 sampel/responden. Hal ini dikarenakan bahwa di tengah masa pandemi covid-19 banyak kuesioner yang tidak kembali dan sebagian besar responden/UMKM enggan maupun merasa takut untuk dimintai waktu dalam mengisi kuesioner.

Adapun variabel yang digunakan dalam penelitian ini dapat dilihat pada tabel di bawah ini :

Tabel 2. Definisi Operasional Variabel

\begin{tabular}{|c|c|c|c|}
\hline Variabel & Definisi & Pengukuran & Sumber \\
\hline $\begin{array}{l}\text { Kepatuhan } \\
\text { Wajib Pajak (Y) }\end{array}$ & $\begin{array}{l}\text { Keadaan dimana } \\
\text { wajib pajak } \\
\text { memenuhi segala } \\
\text { kewajiban } \\
\text { perpajakannya }\end{array}$ & 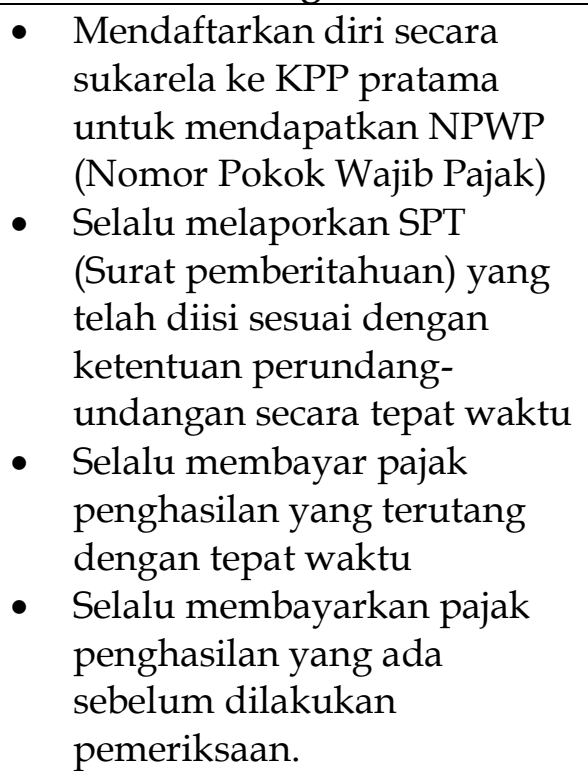 & $\begin{array}{l}\text { Modifikasi } \\
\text { Peneliti dari } \\
\text { (Febriani \& } \\
\text { Kusmuriyanto, } \\
\text { 2015) }\end{array}$ \\
\hline $\begin{array}{l}\text { Literasi Pajak } \\
\left(X_{1}\right)\end{array}$ & $\begin{array}{l}\text { Sejauh mana wajib } \\
\text { pajak memiliki } \\
\text { pengetahuan dan } \\
\text { pemahaman akan } \\
\text { peraturan } \\
\text { perpajakan sehingga }\end{array}$ & $\begin{array}{l}\text { Pengetahuan dan } \\
\text { pemahaman mengenai } \\
\text { nomor pokok wajib pajak ( } \\
\text { NPWP) } \\
\text { - Pengetahuan dan } \\
\text { pemahaman mengenai }\end{array}$ & $\begin{array}{l}\text { Modifikasi } \\
\text { Peneliti } \\
\text { (Fauziah \& } \\
\text { Kusmuriyanto, } \\
\text { 2016) }\end{array}$ \\
\hline
\end{tabular}




\begin{tabular}{|c|c|c|c|}
\hline & $\begin{array}{l}\text { membuat wajib } \\
\text { pajak sadar dan } \\
\text { berlaku taat. }\end{array}$ & $\begin{array}{ll}\text { - } & \text { Peraturan perpajakan terbaru } \\
\text { pengetahuan dan } \\
\text { pemahaman mengenai } \\
\text { sanksi perpajakan } \\
\text { - Pengetahuan dan } \\
\text { pemahaman mengenai } \\
\text { sistem dan prosedur } \\
\text { perpajakan } \\
\text { - Pengetahuan mengenai batas } \\
\text { waktu pembayaran dan } \\
\text { pelaporan SPT }\end{array}$ & \\
\hline $\begin{array}{r}\text { Kualitas } \\
\text { Pelayanan }\left(X_{2}\right)\end{array}$ & $\begin{array}{l}\text { Kemampuan } \\
\text { pelayanan } \\
\text { perpajakan yang } \\
\text { diberikan oleh } \\
\text { individu dan } \\
\text { organisasi terhadap } \\
\text { wajib pajak }\end{array}$ & $\begin{array}{ll}\text { - } & \text { Bukti Fisik (tangibles) } \\
\text { - } & \text { Keandalan (Reability) } \\
\text { - } & \text { Ketanggapan } \\
& \text { (Responsiveness) } \\
\text { - } & \text { Jaminan (Assurance) } \\
\text { - } & \text { Empati (Emphaty) }\end{array}$ & $\begin{array}{l}\text { (Wulan \& } \\
\text { Joharis, 2012) }\end{array}$ \\
\hline $\begin{array}{c}\text { Sanksi } \\
\text { Perpajakan }\left(X_{3}\right)\end{array}$ & $\begin{array}{l}\text { Suatu tindakan } \\
\text { berupa hukuman } \\
\text { bagi wajib pajak } \\
\text { yang melanggar } \\
\text { ketentuan peraturan } \\
\text { perundang- } \\
\text { undangan }\end{array}$ & $\begin{array}{l}\text { - Sanksi bagi tindakan } \\
\text { penghindaran pajak } \\
\text { - Sanksi bagi penyalahgunaan } \\
\text { hak NPWP dan } \\
\text { penyampaian SPT tidak } \\
\text { benar dan tidak lengkap } \\
\text { - Sanksi bagi tindakan wajib } \\
\text { pajak yang kurang bayar } \\
\text { - Sanksi diperlukan untuk } \\
\text { menciptakan kedisiplinan } \\
\text { wajib pajak }\end{array}$ & $\begin{array}{l}\text { Modifikasi } \\
\text { Peneliti dari } \\
\text { (Rahayu, 2017) }\end{array}$ \\
\hline
\end{tabular}

Metode analisis data yang digunakan dalam penelitian ini diantaranya adalah uji kualitas data, analisis deskripsi variabel penelitian, uji asumsi klasik dan analisis regresi berganda. Uji kualitas data digunakan untuk mengetahui validitas dan reliabilitas masing-masing item pertanyaan. Analisis deskripsi variabel penelitian dilakukan untuk memperoleh gambaran jawaban responden atas masing-masing item pertanyaan dengan melihat distribusi frekuensi jawaban. Uji asumsi klasik digunakan untuk mengetahui apakah data yang akan digunakan dalam penelitian ini terbebas dari asumsi klasik atau tidak meliputi uji normalitas, uji heteroskedastisitas, dan uji multikolinieritas. Analisis regresi berganda digunakan untuk menguji hubungan variabel independen terhadap variabel dependen.

\section{HASIL DAN PEMBAHASAN}

\section{Uji Validitas}

Menurut Sujarweni (2016) uji validitas digunakan untuk mengetahui kelayakan butir-butir dalam suatu daftar pertanyaan dalam mendefinisikan suatu variabel. Uji validitas sebaiknya dilakukan pada setiap butir pertanyaan diuji validitasnya. Hasil $r$ hitung dibandingkan dengan $r$ tabel dimana $\mathrm{df}=\mathrm{n}-2$ yaitu $40-2=38$ 
dengan sig 5\% diperoleh nilai $r$ tabel sebesar 0,3120, sehingga jika $r$ tabel $<\mathrm{r}$ hitung maka valid. Berikut ini hasil uji validitas dari masing-masing item pernyataan dari masing-masing variabel penelitian yang digunakan :

Tabel 3. Hasil Uji Validitas Instrumen Variabel

\begin{tabular}{|c|c|c|c|}
\hline $\begin{array}{l}\text { No. item } \\
\text { instrument }\end{array}$ & r- hitung & r-tabel & Keterangan \\
\hline$X_{1.1}$ & 0,674 & 0,3120 & Valid \\
\hline$X_{1} .2$ & 0,780 & 0,3120 & Valid \\
\hline$X_{1} .3$ & 0,651 & 0,3120 & Valid \\
\hline$X_{1.4}$ & 0,740 & 0,3120 & Valid \\
\hline$X_{1.5}$ & 0,571 & 0,3120 & Valid \\
\hline$X_{2.1}$ & 0,696 & 0,3120 & Valid \\
\hline $\mathrm{X}_{2.2}$ & 0,774 & 0,3120 & Valid \\
\hline$X_{2} .3$ & 0,834 & 0,3120 & Valid \\
\hline$X_{3.1}$ & 0,540 & 0,3120 & Valid \\
\hline$X_{3.2}$ & 0,851 & 0,3120 & Valid \\
\hline$X_{3.3}$ & 0,830 & 0,3120 & Valid \\
\hline$X_{3} .4$ & 0,759 & 0,3120 & Valid \\
\hline$Y_{1.1}$ & 0,358 & 0,3120 & Valid \\
\hline$Y_{1.2}$ & 0,468 & 0,3120 & Valid \\
\hline$Y_{1} .3$ & 0,686 & 0,3120 & Valid \\
\hline$Y_{1} .4$ & 0,850 & 0,3120 & Valid \\
\hline$Y_{1.5}$ & 0,634 & 0,3120 & Valid \\
\hline
\end{tabular}

Berdasarkan tabel 3 di atas, dapat dijelaskan bahwa semua item pernyataan tentang literasi pajak $\left(X_{1}\right)$, kualitas pelayanan $\left(X_{2}\right)$, sanksi perpajakan $\left(X_{3}\right)$ dan kepatuhan wajib pajak $(\mathrm{Y})$ memiliki nilai $\mathrm{r}$ hitung lebih besar dari $\mathrm{r}$ tabel sehingga dapat disimpulkan bahwa semua item pernyataan valid.

\section{Uji Reliabilitas}

Menurut (Sujarweni, 2016), uji reliabilitas berfungsi untuk mengetahui tingkat konsistensi suatu angket yang digunakan oleh peneliti sehingga angket tersebut dapat dihandalkan untuk mengukur variabel penelitian. Dasar pengambilan keputusan yang digunakan adalah jika nilai cronbach's alpha $>0,60$ maka kuesioner atau angket dinyatakan reliabel atau konsisten begitu sebaliknya jika nilai cronbach's alpha < 0,60 maka kuesioner atau angket dinyatakan tidak reliabel atau tidak konsisten. Berikut ini hasil uji reliabilitas sebagaimana tersaji pada tabel di bawah ini :

Tabel 4. Hasil Uji Realibilitas dari Instrument Kuisioner

\begin{tabular}{lcc}
\hline Variabel & Nilai Cronbach's Alpha & Keterangan \\
\hline Literasi pajak & 0,677 & Reliabel \\
Pelayanan & 0,653 & Reliabel \\
Sanksi pajak & 0,735 & Reliabel \\
Kepatuhan wajib pajak & 0,652 & Reliabel \\
\hline
\end{tabular}


Berdasarkan tabel 4 di atas, dapat disimpulkan bahwa nilai cronbach's alpha untuk setiap pernyataan dalam kuesioner reliabel dan item pernyataan yang digunakan akan mampu memperoleh data yang konsisten.

\section{Analisis Statistik Deskriptif}

Untuk memperoleh gambaran atas jawaban responden atas masing-masing item pernyataan, peneliti melakukan analisis dengan membuat tabulasi dan menghitung persentase untuk setiap item pernyataan yang diajukan pada setiap variabel yang hasilnya dapat diuraikan sebagai berikut: Pertama, persepsi UMKM tentang literasi pajak yang terdiri dari 5 item pernyataan diperoleh nilai rata-rata sebesar 4,01. Dengan demikian tingkat persepsi UMKM tentang literasi pajak berada dalam kategori tinggi. Hal ini menunjukkan bahwa UMKM pada dasarnya memiliki pengetahuan dan pemahaman tentang perpajakan khususnya pengenaan pajak bagi UMKM.

Kedua, persepsi UMKM tentang kualitas pelayanan yang terdiri dari 3 item pernyataan diperoleh nilai rata-rata sebesar 4,26. Dengan demikian tingkat persepsi UMKM tentang kualitas pelayanan berada dalam kategori sangat baik. Hal ini menunjukkan bahwa sebagian besar UMKM yang melaksanakan kewajiban perpajakannya mempunyai pengalaman langsung dan memiliki persepsi yang baik mengenai pelayanan yang diberikan oleh fiskus sehingga memberikan kepuasan tersendiri bagi masing-masing wajib pajak.

Ketiga persepsi UMKM tentang sanksi perpajakan yang terdiri dari 4 item pernyataan diperoleh nilai rata-rata sebesar 3,38. Dengan demikian, tingkat persepsi UMKM tentang sanksi perpajakan berada dalam kategori cukup setuju. Hal ini menunjukkan bahwa UMKM pada dasarnya memandang pengenaan sanksi perpajakan bagi wajib pajak yang melanggar aturan merupakan alat pencegah agar wajib pajak tidak melanggar norma perpajakan sehingga kepatuhan wajib pajak akan ditentukan berdasarkan pengamatan maupun pengalaman langsung mengenai seberapa kuat sanksi pajak akan mampu mendukung perilaku wajib pajak untuk taat pajak.

Keempat, persepsi UMKM tentang kepatuhan wajib pajak yang terdiri dari 5 item pernyataan diperoleh nilai rata-rata sebesar 3,95. Dengan demikian, tingkat persepsi UMKM tentang kepatuhan wajib pajak berada dalam kategori tinggi. Hal ini menunjukkan bahwa UMKM selaku wajib pajak mempunyai kesediaan untuk memenuhi kewajiban pajaknya sesuai aturan yang berlaku karena penerimaan dari sektor perpajakan terbilang besar dan digunakan untuk pembiayaan negara.

\section{Analisis Regresi Berganda}

Sebelum melakukan uji analisis regresi berganda, terlebih dahulu diakukan uji asumsi klasik dimana hasil uji asumsi klasik menunjukkan data terdistribusi dengan normal, tidak terjadi multikolonieritas dan tidak terjadi heteroskedastisitas. Selanjutnya teknik regresi berganda digunakan untuk menguji pengaruh dua atau lebih variabel independen terhadap suatu variabel dependen. Untuk menentukan persamaan regresinya,peneliti menggunakan metode enter, hasil uji regresi linear berganda terhadap ketiga variabel independen yaitu literasi pajak, kualitas pelayanan dan sanksi perpajakan dapat dilihat pada tabel 5. 
Tabel 5. Hasil Uji Regresi Berganda

\begin{tabular}{|c|c|c|c|c|c|c|}
\hline \multicolumn{7}{|c|}{ Coefficients $^{a}$} \\
\hline \multirow[t]{2}{*}{ Model } & & \multicolumn{2}{|c|}{$\begin{array}{l}\text { Unstandardized } \\
\text { Coefficients }\end{array}$} & \multirow{2}{*}{$\begin{array}{c}\text { Standardize } \\
\mathrm{d} \\
\text { Coefficients } \\
\text { Beta }\end{array}$} & \multirow[t]{2}{*}{$\mathrm{T}$} & \multirow[t]{2}{*}{ Sig. } \\
\hline & & & 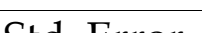 & & & \\
\hline \multirow[t]{5}{*}{1} & (Constant) & 1.720 & .539 & & 3.189 & .003 \\
\hline & Literasi & .124 & .130 & .160 & .959 & .344 \\
\hline & Pajak & & & & & \\
\hline & Pelayanan & 271 & 135 & 328 & 2.012 & 052 \\
\hline & Sanksi & 171 & .062 & 388 & 2.773 & .009 \\
\hline \multicolumn{7}{|c|}{ a. Dependent Variable: Kepatuhan Wajib Pajak } \\
\hline
\end{tabular}

Berdasarkan tabel 5 di atas dapat dijelaskan bahwa variabel literasi pajak memiliki tingkat signifikansi sebesar 0,344 >0,05 sehingga dapat disimpulkan bahwa literasi pajak tidak berpengaruh signifikan terhadap kepatuhan wajib pajak UMKM. Variabel kualitas pelayanan memiliki tingkat signifikansi sebesar 0,052 >0,05 sehingga dapat disimpulkan kualitas pelayanan tidak berpengaruh signifikan terhadap kepatuhan wajib pajak UMKM. Selanjutnya, variabel sanksi perpajakan memiliki tingkat signifikansi sebesar 0,009 $<0,05$ sehingga dapat disimpulkan bahwa sanksi perpajakan berpengaruh signifikan terhadap kepatuhan wajib pajak UMKM.

\section{Uji Kecocokan Model}

Berdasarkan uji kecocokan model diperoleh nilai adjusted $\mathrm{R}^{2}$ sebesar 0,302 . Hal ini menandakan bahwa variasi variabel literasi pajak, kualitas pelayanan dan sanksi perpajakan dapat menjelaskan sebesar 30,2\% variasi variabel kepatuhan wajib pajak sedangkan sisianya sebesar $69,8 \%$ kepatuhan wajib pajak dijelaskan oleh faktor lain yang tidak termasuk dalam penelitian ini.

\section{Pembahasan}

Hipotesis pertama menyatakan bahwa literasi pajak berpengaruh signifikan terhadap kepatuhan wajib pajak UMKM. Berdasarkan hasil pengujian hipotesis menunjukkan bahwa literasi pajak tidak berpengaruh signifikan dan mempunyai hubungan positif terhadap kepatuhan wajib pajak sehingga menolak hipotesis pertama $\left(\mathrm{H}_{1}\right)$. Hal ini menunjukkan bahwa literasi pajak pada dasarnya berkaitan dengan kemampuan seseorang dalam membaca dan memahami informasi serta menindaklanjuti informasi tersebut melalui suatu keputusan. Artinya bahwa literasi pajak berkaitan erat dengan pengetahuan dan pemahaman yang baik dan benar oleh wajib pajak tentang perpajakan sebagaimana sejalan dengan apa yang dikemukakan oleh (Fauziah \& Kusmuriyanto, 2016) bahwa tingkat pengetahuan dan pemahaman yang dimiliki seseorang akan mempengaruhi tindakan yang akan diambil oleh orang tersebut. Dalam teori pembelajaran sosial yang dikembangkan oleh (Robbins \& Judge, 2008) bahwa wajib pajak dapat belajar dengan mengamati sistem dan peraturan pajak yang terus mengalami perubahan dari waktu ke waktu dengan melakukan 
pengamatan dan pengalaman langsung sehingga menjadi dasar bagi wajib pajak untuk memilih berperilaku patuh atau tidak. Namun, tinggi rendahnya literasi pajak yang dimiliki oleh wajib pajak dalam hal ini adalah wajib pajak UMKM yang menjadi responden dalam penelitian ini tidak menjamin wajib pajak tersebut untuk berperilaku patuh dan taat memenuhi kewajiban perpajakannya selama pengetahuan dan pemahaman yang dimiliki wajib pajak tersebut tidak diaplikasikan. Hal ini bisa dilihat dari karakteristik responden dari tingkat pendidikan yang sebagian besar responden memiliki tingkat pendidikan rendah yang paham dan tahu tentang bidang perpajakan namun selama ini mereka enggan untuk memenuhi kewajiban perpajakannya/mengaplikasikannya dikarenakan para pengelola UMKM merasa masih terbebani dengan adanya biaya-biaya tambahan selain biaya produksi. Berlakunya sistem pemungutan pajak yaitu self assessment system yang mengharuskan wajib pajak untuk mendaftar, menyetorkan, melaporkan dan menghitung sendiri besar pajaknya tentu butuh kesadaran wajib pajak untuk taat dan patuh memenuhi kewajibannya dan tidak cukup dengan tingkat pengetahuan dan pemahaman yang dimilikinya. Hal ini sejalan dengan apa yang disampaikan oleh (Brata et al., 2017) bahwa wajib pajak yang sadar pajak akan memiliki keyakinan mengenai pentingnya membayar pajak sehingga semakin tinggi tingkat kesadaran wajib pajak maka pemahaman dan pelaksanaan kewajiban perpajakan semakin baik dan dapat meningkatkan kepatuhan. Hasil penelitian ini mendukung penelitian yang dilakukan (Hardiningsih \& Yulianawati, 2011; Roseline \& Rusydi, 2012). Namun bertolak belakang dengan penelitian (Fahluzy \& Agustina, 2014; Febriani \& Kusmuriyanto, 2015; Ilhamsyah et al., 2016; Tambun, 2016).

Hipotesis kedua menyatakan bahwa kualitas pelayanan berpengaruh signifikan terhadap kepatuhan wajib pajak UMKM. Berdasarkan hasil pengujian hipotesis menunjukkan bahwa kualitas pelayanan tidak berpengaruh signifikan dan mempunyai hubungan positif terhadap kepatuhan wajib pajak sehingga menolak hipotesis kedua $\left(\mathrm{H}_{2}\right)$. Pada dasarnya kewajiban perpajakan merupakan suatu kewajiban yang dapat dipaksakan menurut undang-undang dan dianggap utang bila wajib pajak tidak melaksanakan kewajibannya. (Brata et al., 2017) mengemukakan bahwa pelayanan pajak dapat dikaitkan dengan normative beliefs yang merupakan salah satu faktor dari Theory of Planned Behavior dimana ketika akan melakukan sesuatu, maka individu akan memiliki keyakinan tentang harapan normatif dari orang lain dan motivasi untuk memenuhi harapan tersebut. Merujuk pernyataan tersebut hasil penelitian ini membuktikan bahwa kualitas pelayanan masih belum dapat meningkatkan kepatuhan wajib pajak UMKM dalam melaksanakan kewajiban perpajakannya dimana kualitas pelayanan dari aparat pajak belum dapat memenuhi atau melebihi harapan dari wajib pajak UMKM. Menurut (Robbins \& Judge, 2008) yang dikutip dari (Fauziah \& Kusmuriyanto, 2016) bahwa dalam teori pembelajaran sosial, seorang wajib pajak akan taat membayar pajak apabila wajib pajak mempunyai pengalaman langsung mengenai pelayanan yang diberikan fiskus. Dalam penelitian (Masruroh \& Zulaikha, 2013) menjelaskan juga bahwa walaupun sistem perpajakan di era saat ini pelayanannya sudah menggunakan perkembangan teknologi informasi berupa fasilitas e-SPT, e-Faktur, maupun e-Filling, namun dikarenakan adanya oknumoknum yang menyalahgunakan dana pajak membuat kepercayaan wajib pajak kepada fiskus atau aparat pajak menjadi turun. Hasil penelitian ini sejalan dengan penelitian 
dari (Brata et al., 2017; Masruroh \& Zulaikha, 2013) yang membuktikan kualitas pelayanan tidak berpengaruh signifikan terhadap kepatuhan wajib pajak. Namun bertolak belakang dengan penelitian dari (As'ari \& Erawati, 2018; Febriani \& Kusmuriyanto, 2015; Pranata \& Setiawan, 2015; Rustiyaningsih, 2017).

Hipotesis ketiga menyatakan bahwa sanksi perpajakan berpengaruh signifikan terhadap kepatuhan wajib pajak UMKM. Berdasarkan hasil pengujian hipotesis menunjukkan bahwa sanksi perpajakan berpengaruh signifikan dan mempunyai hubungan positif terhadap kepatuhan wajib pajak sehingga mendukung hipotesis ketiga $\left(\mathrm{H}_{3}\right)$. Hal ini menunjukkan bahwa berdasarkan Undang-Undang di bidang perpajakan, pengenaan sanksi pajak bertujuan untuk mencegah atau meminimalisir agar wajib pajak tidak melanggar norma perpajakan. Wajib pajak akan patuh apabila memandang sanksi pajak akan lebih banyak merugikannya dikarenakan semakin banyak sisa tunggakan pajak yang harus dibayar wajib pajak maka akan semakin berat bagi wajib pajak untuk melunasinya. Oleh karena itu, meskipun wajib pajak tidak mendapatkan penghargaan atas kepatuhannya dalam memenuhi kewajiban, wajib pajak akan dikenakan hukuman apabila lupa atau sengaja tidak melaksanakan kewajiban perpajakannya. Pengamatan dan pengalaman langsung menjadi dasar bagi wajib pajak untuk menilai pemberian sanksi dan memilih untuk berperilaku taat atau tidak. Hasil penelitian ini mendukung penelitian yang dilakukan oleh (Brata et al., 2017; Pranata \& Setiawan, 2015; Rahayu, 2017) yang menemukan bahwa sanksi perpajakan berpengaruh signifikan terhadap kepatuhan wajib pajak, dimana sanksi pajak harus lebih ditegaskan pengenaannya kepada wajib pajak yang melakukan kecurangan dan enggan memenuhi kewajiban perpajakannya sehingga dengan adanya sanksi perpajakan ini akan menjadi motivasi dalam meningkatkan kepatuhan wajib pajak khususnya pajak UMKM. Namun penelitian ini bertolak belakang dengan hasil temuan yang dilakukan oleh (Fauziah \& Kusmuriyanto, 2016; Rahmawati \& Yulianto, 2018) yang justru menemukan bahwa sanksi perpajakan tidak berpengaruh signifikan terhadap kepatuhan wajib pajak.

\section{KESIMPULAN DAN SARAN}

Berdasarkan hasil penelitian dan pembahasan, penelitian ini menyimpulkan bahwa literasi pajak dan kualitas pelayanan tidak berpengaruh signifikan terhadap kepatuhan wajib pajak UMKM. Sementara itu, sanksi perpajakan berpengaruh signifikan terhadap kepatuhan wajib pajak UMKM. Dari hasil penelitian itu dijelaskan bahwa seorang wajib pajak yang memiliki tingkat literasi (pengetahuan dan pemahaman) yang tinggi dan rendah mengenai perpajakan tidak menjamin untuk berperilaku patuh atau tidak tanpa dibarengi dengan adanya kesadaran dan kemauan dalam membayar pajak. Begitu juga dengan kualitas pelayanan, walaupun pelayanan di era reformasi perpajakan saat ini yang sudah menggunakan aplikasi teknologi informasi namun belum sepenuhnya efektif dan efisien dalam memudahkan wajib pajak untuk memenuhi kewajiban perpajakannya. Hal ini bisa dilihat bahwa sebagian besar responden khususnya UMKM banyak yang belum memahami penggunaan aplikasi teknologi informasi seperti e-SPT, e-Faktur, e-Filling maupun aplikasi lainnya mengingat bahwa secara manual saja mereka para UMKM masih banyak yang merasa kesulitan. Mendukung hal tersebut, dalam upaya mencegah wajib pajak yang 
melanggar aturan maupun enggan dalam membayar pajak, pihak pemerintah dalam hal ini Direktorat Jenderal Pajak telah tegas dalam memberikan sanksi baik berupa sanksi administrasi maupun sanksi pidana. Hal ini tidak lain bertujuan untuk memberikan efek jera bagi para pelanggar pajak dalam upaya meningkatkan kepatuhan wajib pajak yang tentunya pendapatan negara semakin meningkat.

Penelitian ini tidak terlepas dari keterbatasan yaitu dari segi sampel dalam penelitian ini masih terbilang sedikit mengingat wajib pajak UMKM banyak yang merasa takut dan enggan untuk menjadi responden dalam penelitian ini, di samping itu di tengah masa pandemi covid-19 banyak kuesioner yang tidak kembali sehingga hasil ini tidak bisa digeneralisir untuk seluruh wilayah yang ada di Nusa Tenggara Barat. Untuk itu, peneliti menyarankan bahwa dalam upaya meningkatkan literasi pajak diharapkan kepada Kantor Pelayanan Pajak setempat terus dan gencar melakukan sosialisasi, memberikan edukasi tentang pajak maupun pelatihanpelatihan di bidang perpajakan sehingga wajib pajak UMKM lebih memahami dan sadar tentang kewajiban perpajakan. Pendekatan personal atau persuasif perlu digalakkan. Tidak hanya itu saja, dalam peningkatan kepatuhan wajib pajak di setiap pelosok ada pojok pajak yang nantinya akan melayani wajib pajak yang berada di pelosok desa sehingga akan sangat memudahkan wajib pajak untuk memenuhi kewajibannya. Hasil penelitian ini bisa dijadikan referensi bagi peneliti selanjutnya yang ingin mengkaji masalah sejenis untuk objek yang berbeda.

\section{DAFTAR PUSTAKA}

As'ari, N. G., \& Erawati, T. (2018). Pengaruh Pemahaman Peraturan Perpajakan, Kualitas Pelayanan, Kesadaran Wajib Pajak dan Sanksi Pajak Terhadap Kepatuhan Wajib Pajak Orang Pribadi (Studi Empiris pada Wajib Pajak Orang Pribadi Kecamatan Rongkop). Akuntansi Dewantara, 2(1), 46-55. https://doi.org/10.29230/ad.v2i1.2221

Astina, I. P. S., \& Setiawan, P. E. (2018). Pengaruh Pemahaman Peraturan Perpajakan , Kualitas Pelayanan Fiskus dan Kesadaran Wajib Pajak Terhadap Tingkat Kepatuhan WPOP. E-Jurnal Akuntansi Universitas Udayana, 23(1), 1-30.

Brata, J. D., Yuningsih, I., \& Kesuma, A. I. (2017). Pengaruh Kesadaran Wajib Pajak, Pelayanan Fiskus, dan Sanksi Pajak terhadap Kepatuhan Wajib Pajak Orang Pribadi yang Melakukan Kegiatan Usaha dan Pekerjaan Bebas di Kota Samarinda. Forum Ekonomi, 19(1), 69-81.

bps.go.id Depkop. (2018). Perkembangan Data Usaha Mikro, Kecil, Menengah (UMKM) Dan Usaha Besar (UB) Tahun 2017-2018. http:/ / www.depkop.go.id/data-umkm

Fahluzy, S. F., \& Agustina, L. (2014). Faktor-Faktor Yang Mempengaruhi Kepatuhan Membayar Pajak UMKM di Kabupaten Kendal. Accounting Analysis Journal, 3(3), 399-406.

Fauziah, N., \& Kusmuriyanto. (2016). Faktor-Faktor Yang Mempengaruhi Kepatuhan Implementasi Peraturan Pemerintah Nomor 46 Tahun 2013. Accounting Analysis Journal, 5(2), 11-20. 
Febriani, Y., \& Kusmuriyanto. (2015). Analisis Faktor-Faktor Yang Mempengaruhi Kepatuhan Wajib Pajak. Accounting Analysis Journal, 4(4), 1-13.

Hardiningsih, P., \& Yulianawati, N. (2011). Faktor-Faktor Yang Mempengaruhi Kemauan Membayar Pajak. Dinamika Keuangan Dan Perbankan, 3(1), 126-143.

Ibda, H. (2019). Penguatan Literasi Perpajakan Melalui Strategi Gebuk (Gerakan Membuat Kartu) NPWP Pada Mahasiswa. Ekonomi Pendidikan Dan $\begin{array}{lll}\text { Kewirausahaan, } & 7(2), & 83-98 .\end{array}$ https://journal.unesa.ac.id/index.php/jepk/article/view/4370/3517

Ilhamsyah, R., Endang, M. G. W., \& Dewantara, R. Y. (2016). Pengaruh Pemahaman dan Pengetahuan Wajib Pajak Tentang Peraturan Perpajakan, Kesadaran Wajib Pajak, Kualitas Pelayanan, Dan Sanksi Perpajakan Terhadap Kepatuhan Wajib Pajak Kendaraan Bermotor (Studi Samsat Kota Malang). Jurnal Perpajakan (JEJAK)|, 8(1), 1-9. http://perpajakan.studentjournal.ub.ac.id/index.php/ perpajakan/article/view/219/214

Kementerian Pendidikan dan Kebudayaan. (2016). Kamus Besar Bahasa Indonesia Daring. https://kbbi.kemdikbud.go.id/

Mangoting, Y., \& Sadjiarto, A. (2013). Pengaruh Postur Motivasi Terhadap Kepatuhan Wajib Pajak Orang Pribadi. Jurnal Akuntansi Dan Keuangan, 15(2), 106-116. https://doi.org/10.9744/jak.15.2.106-116

Mardiasmo. (2018). Perpajakan. Andi Offset.

Masruroh, S., \& Zulaikha. (2013). Pengaruh Kemanfaatan NPWP, Pemahaman Wajib Pajak, Kualitas Pelayanan, Sanksi Perpajakan Terhadap Kepatuhan Wajib Pajak (Studi Empiris Pada WP OP di Kabupaten Tegal). Diponegoro Journal Of Accounting, 2(4), 1-15.

Mucglobal. (2020). Melambat, Jumlah Pembayar Pajak UMKM Hanya Tumbuh 23\% . https://mucglobal.com/id/news/1879/melambat-jumlah-pembayar-pajakumkm-hanya-tumbuh-23, diakses 3 Oktober 2020

Peraturan Pemerintah Nomor 23 Tahun 2018 Tentang Pajak Penghasilan Atas Penghasilan Dari Usaha Yang Diterima Atau Diperoleh Wajib Pajak Yang Memiliki Peredaran Bruto Tertentu

Pertiwi, N. P. D. (2020). Problematika Penurunan Tarif Pajak UMKM. https://www.pajakku.com/read/5dafbcd44c6a88754c0880a2/ProblematikaPenurunan-Tarif-Pajak-UMKM, diakses 3 Oktober 2020

Pranata, P. A., \& Setiawan, P. E. (2015). Pengaruh Sanksi Perpajakan, Kualitas Pelayanan Dan Kewajiban Moral Pada Kepatuhan Wajib Pajak. E-Jurnal Akuntansi Universitas Udayana, 10(2), 456-473.

Rahayu, N. (2017). Pengaruh Pengetahuan Perpajakan, Ketegasan Sanksi Pajak, Dan Tax Amnesty Terhadap Kepatuhan Wajib Pajak. Akuntansi Dewantara, 1(1), 1530. 
Rahmawati, R., \& Yulianto, A. (2018). Analysis of the Factors Affecting Individual Taxpayers Compliance. Accounting Analysis Journal, 7(1), 17-24. https://doi.org/10.15294/aaj.v5i3.18411

Robbins, S. P., \& Judge, T. P. (2008). Perilaku Organisasi (12th ed.). Salemba Empat.

Roseline, R., \& Rusydi, M. K. (2012). Analisis Faktor-Faktor Yang Mempengaruhi Kepatuhan Wajib Pajak Dalam Mengukuhkan Diri Sebagai Pengusaha Kena Pajak. Jurnal Ilmiah Mahasiswa FEB Universitas Brawijaya, 5(2), 1-12.

Rustiyaningsih, S. (2017). Faktor Yang Mempengaruhi Kepatuhan Wajib Pajak Orang Pribadi Dalam Membayar Pajak. Widya Warta, 01, 114-128.

Saputro, R. F. (2018). Membangun Rumah Literasi Pajak. https://news.ddtc.co.id/ membangun-rumah-literasi-pajak-11742?page_y=305, diakses tanggal 9 Oktober 2020

Sugiyono. (2019). Metode Penelitian Kuantitatif Kualitatif dan R\&D (2nd ed.). CV. Alfabeta.Sujarweni, W. (2016). Kupas tuntas penelitian akuntansi dengan SPSS (Mona (ed.); V). Pustaka Baru Press.

Supadmi, N. L. (2009). Meningkatkan Kepatuhan Wajib Pajak Melalui Kualitas Pelayanan. Jurnal Ilmiah Akuntansi Dan Bisnis, 4(2), 1-14.

Tambun, S. (2016). Anteseden Kepatuhan Wajib Pajak Orang Pribadi dan Moderasi Sosialisasi Perpajakan. Media Akuntansi Perpajakan, 1(1), 26-40.

Undang-Undang Nomor 28 Tahun 2007 tentang Ketentuan Umum dan Tata Cara Perpajakan Undang-Undang Nomor 20 Tahun 2008. Tentang Usaha Mikro Kecil dan Menengah.

Undang-Undang Nomor 16 Tahun 2009 Tentang Penetapan Peraturan Pemerintah Pengganti Undang-Undang Nomor 5 Tahun 2008 Tentang Perubahan Keempat Atas Undang-Undang Nomor 6 Tahun 1983 Tentang Ketentuan Umum dan Tata Cara Perpajakan Menjadi Undang-Undang

Wardani, D. K., \& Wati, E. (2018). Pengaruh Sosialisasi Perpajakan Terhadap Kepatuhan Wajib Pajak Dengan Pengetahuan Perpajakan Sebagai Variabel Intervening ( Studi Pada Wajib Pajak Orang Pribadi di KPP Pratama Kebumen ). Nominal, VII(1), 33-54.

Wiyarni, Hartini, \& Djuharni, D. (2018). Pengaruh Kompleksitas Peraturan Perpajakan,Kualitas Layanan, Sanksi Perpajakan Dan Pemeriksaan Terhadap KepatuhanPajak.Jurnal Akuntansi Kontemporer (JAKO), 10(1), 14-23.

Wulan, S., \& Joharis, M. N. (2012). Analisis Kualitas Pelayanan Terhadap Kepuasan Wajib Pajak Pada Kantor Pelayanan Pajak Pratama Kedaton Di Bandar Lampung. Jurnal Manajemen Dan Bisnis, 2(2), 181-200.

Wulandari, L. A. (2020). Perpajakan Dasar untuk UMKM Pemula. https:// www.pajak.go.id/id/artikel/perpajakan-dasar-untuk-umkm-pemula 
Yusro, H. W., \& Kiswanto. (2014). Pengaruh Tarif Pajak, Mekanisme Pembayaran Pajak Dan Kesadaran Membayar Pajak Terhadap Kepatuhan Wajib Pajak UMKM di Kabupen Jepara. Accounting Analysis Journal, 3(4), 429-436. 